\title{
APPROPRIATED ISLAM: HINDU-MUSLIM CULTURAL SYMBIOSIS AND MATRILINY AMONG THE MAPPILAS OF KERALA
}

\author{
MUSTHAFA FAROOK \\ Faculty of History, S.S.College, \\ Areacode, Malappuram-673645, Kerala, India \\ E-mail address: musthafafarookp@gmail.com
}

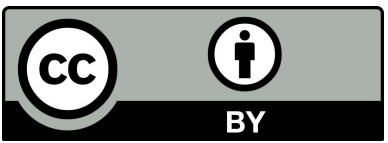

\author{
HASKERALI E.C \\ UGC Research Awardee, Dept. of Malayalam \& Kerala Studies, \\ University of Calicut.673635 Kerala, India \\ E-mail address: haskeraligarh@gmail.com
}

\begin{abstract}
Marumakkathayam or the matrilineal form of inheritance is an important social institution that emerged in Kerala around the beginning of Ninth Century A.D. Some prominent sections in the Hindu community practised this system. Joint families under the headship of the eldest female member was a peculiar feature of this system. The male members were visitors of the household and the inheritance of the property went to the children of the female members. Gradually, the women became the owners of property. The system was also prevalent among the Mappilas of the land. Different reasons are attributed for the emergence of matriliny among them. But the conversion of the matrilineal Hindus to Islam is the real cause for adaptation of this institution in Muslim society.

Keywords: matriliny, mappila, tharavad, karanavan, mut'a
\end{abstract}

Islam is seen as a patriarchal religion and treats women as subservient to men and women live under the protection and control of their husbands. Exploring the unusual matrilineal system family among the Muslims in Kerala, one is struck by the question, why did the followers of Islam, which has a monolithic doctrinal framework, embrace such an institution that is deemed as non-Islamic by the clergy? This paper tries to answer the question why a male-controlled religion like Islam has assimilated matriliny into its fold.

Marumakkathayam or a matrilineal form of inheritance is an important social institution that emerged in Kerala around the beginning of the medieval period i.e. Ninth Century A.D. The political anarchy created by the decay and fall of the Second Chera Empire and the subsequent socio-political developments set the stage for the development of this system. At the end of the $12^{\text {th }}$ Century, the 
institution became the norm of the social life of Kerala and other social institutions like janmi system (feudalism) and devadasi system strengthened its spirit and structure. The social, economic and cultural aspects of the contemporary life of the period were influential in the development of this institution.

\section{MARUMAKKATHAYAM: STRUCTURE AND FUNCTIONS}

Matriliny is the organization of life based on ajoint family system on the foundation of one's ancestral home or tarawad. The institution functioned through the joint family system via tarawad. A tarawad was a joint family consisting of all the descendents of a common ancestress in the female line. The mother and all her children, all her grandchildren by the daughters, all her brothers and sisters and all the descendents on the sister's side lived together in the same home sharing a common kitchen and enjoying all the property and after her death, they shared her property with one another (Sreedhara Menon, 2008, p. 233). However, the children of the male members had to leave the tarawad. Such children had property rights in their mother's tarawad (Kurup, \& Ismail 2008, p. 32). It was the mother who formed the stock of the descent and kinship as well as the rights to property were traced through females and not through males. The tarawad membership was acquired by birth. Every member, male or female, had an equal interest in the family property. The tarawad property was the joint property of all the members and each member had the right of maintenance from it, but none could claim in partition. This institution is centered upon women. It gave protection to women compared to their counterparts in patrilineal families. Women were the stock of the land title and it was through them that the tarawad name was transmitted from one generation to another. She had a birth right over tarawad property and this lasted throughout her life. A big tarawad was composed of several numbers of residents and vast landed properties. The property of the tarawad was held in common and partition was not allowed. The head and manager of the tarawad was the senior-most male member of the family called the karanavan. The literal meaning of the term is one who is accountable and responsible. He was an agent who represented the tarawad but, not its owner.

The Nair community, who were the traditional warriors of the Kerala rulers, practiced this system widely. Nairs were the warrior class in the region and they constituted the military wing of the kings of the state. The emergence of innumerable kings after the decline of the Chera state led to frequent warfare in the land and the Nairs got little time to attend to their household affairs. The absence of the male members in the Nair families due to their engagement on the battlefields entailed women to shoulder the responsibilities of the family and they gradually became the custodians of the families. Joint families and the headship of the eldest male member became the peculiar feature of the matrilineal system. The other male members were often visitors of the household and the inheritance of the property went to the children of the female 
members. Gradually, the women became the owners of the property and Nair women had to depend on their wives for their economic needs. Other communities in Hinduism like Ezhavas, Samantans and Ambalavasis also followed this system ${ }^{14}$. Inheritance and succession through the sister's children in the female line tracing descent from a common ancestress. A large group of people descended from a female living together in a tarawad or ancestral house, the basic unit of this system.

As mentioned above, marumakkathayam was practiced by various castes of the Hindu community. But interestingly, the system was also prevalent among the Mappilas of coastal areas of Malabar ${ }^{15}$. The Muslims of North Malabar, some coastal areas of Kerala like Cannannore, Tellichery, Mahe, Calicut and Ponnani as well as the people of Laccadive, Minicoy and Amindivi islands practiced this system(Ibrahim Kunju, 1989, p. 174). Generally, Islam is a patriarchal religion and treats women as subservient to men and women live under the protection and control of their husbands. Islamic scriptures contain many references about the status of women which says that they should live according to the likes of their husbands and they are entitled to inherit only half of the share of men. Islamic society is patriarchal and it upholds a patrilineal system of inheritance. In Arabia Islam had established patriliny by obliterating the elements of matriarchy and reorganized the family life by placing the man at the centre. Although there are some differences between this system and the same among the Nairs in the medieval period, the structure, the nature and the character of both were the same.

\section{CAUSES FOR MATRILINY AMONG THE MAPPILAS}

The prevalence of marumakkathayam among the Mappilas is a peculiar feature of Kerala society. Islam insists that a man provide for the maintenance of his family. Providing food, shelter, clothes and other necessities of life for wife as well as for the children - is his responsibility and a wife is not expected to share that duty, and he has no right in the income she draws. Thus, it is apparent that certain factors that were not related to the tenets of Islam led to the emergence of matriliny among the Mappilas.

Different views are expressed about the circumstances which led to the origin of matriliny among the Muslims. Many scholars who have worked on the social life of Kerala hold the view that Muslims accepted matriliny from the Nair community as a result of intermarriage and conversion (Kunjan Pillai,

14 William Logan quotes Herman Gundert that some 26 castes in Hinduism practiced this system in Kerala: (1) The 17 Brahmin illams in Payyannur, (2) Kshatriyas, (3)Tirumulpad (4) Nairs (5) Urali (6) Andor (7) Pallichan (8) Kushavan (9) Vyabari (10) Kolayan (11) Chembotti (12) Pisharadi (13) Variyan (14) Nambuthiri (15) Teyambadi (16) Maran (17) Poduval (18) Kuttunambi (19) Attikurichi (20) Unnitiri (21) Eradi (22) Vallodi (23) Nedungadi (24) Veluttedan (25) Chaliyan and (26) Tiyan in North and Travancore are these castes (Logan, 2000, p. 154).

15 Mappilas are the people evolved from the marital relationships between native women with the Arabs who settled in Kerala for trade purposes. 
1970; Miller, 1976; Sreedhara Menon, 2008). Supporters of this view point out that the institution of matriliny was associated with the Nair practice of polyandry (Miller, 1976, p. 252). Since the Nairs were the adherents of this tradition, they carried it on along with many other social practices even after their conversion to Islam. The conversion to Islam from the Hindu community did not make the converts renounce their old practices. A vast majority of the Indian Muslims are descendants of early converts from Hinduism and most of them have retained many cultural traits of their previous faith. Even casteism survives in Indian Muslim society in various forms. While adhering to the essential tenets of Islam, the converts have tended to retain their social and cultural mores. Spread over wide areas and in a diversity of cultures, Islam has shown remarkable flexibility by evolving major adjustments with local customs and practices; kinship and legal systems; and political and economic structures. South India presents many instances of this and the Malabar is a fascinating example.

In many areas of social life the Mappilas have absorbed elements of Kerala culture including such customs as tying the tali on the occasion of marriage, paying dowry to the bridegroom and purificatory ablutions after birth (Miller, 1976, p. 252). C. A. Innes, the author of Madras District Gazetteers, observed that Mappilas engaged in heretic and distorted practices, though he felt that they were devout practitioners of the religion. They engaged in witchcraft despite "Quranic condemnation"; "canonized" Tangals (spiritual leaders or Sufis mainly having Arab genealogy) and made shrines on their tombs (called as Makham or Jaram). It is noticeable that the Mappila notion of jin and shaitan (evil powers) correspond to the Hindu demons and were propitiated in the same way; Mappilas use wooden figures in magic; and also believe in the evil eye and its bad effects (Innes, 1987, p. 196); and the principal social ceremonies have similarities with Hindu rituals. The cultural practices of Mappilas like ritual tying of tali (symbol of marriage), use of music, tom-toms, and exchange of betals (tobacco) in ceremonies are borrowings from Hindus, mainly those of lower strata of the society.

The support and encouragement given by the rulers to the Muslim traders led to the conversion of many natives to Islam. The thriving conditions of the Mappila settlements of the period can be directly attributed to their economic role as merchants in a land where rulers were reliant on commerce for a major portion of their income. The Arab Muslims linked the economy of Malabar with the networks of international trade, and the local rulers were eager to make concessions to attract them to their ports (Dale, 1980, p. 29). Zamorin, the ruler of Calicut had encouraged many Hindus to convert to Islam as the Muslims were at the forefront against the enemies of the country. Zamorin's power and prestige arose from his coalition with the Mappilas and Arab traders. The assistance of the Arabs helped him, whose chief source of income was customs duty, to monopolize the trade, and militarily he gained additional loyal forces to supplement his traditionally militant but unstable Nair fighters for his policy of aggrandizement (Miller, 1976, p. 54). He had even directed every 
fishermen family of his dominion to bring up one or more male members as Muslims (Innes, 1987, p. 186).

When different castes that practiced matriliny got Islamized they continued their system in the new religion also. In the case of the dynasty of the Ali Rajas of Kannur, the only Muslim royal family in Malabar, the influence of conversion was noticeable in their habitual life. K. K. N. Kurup, who made a detailed study of the Ali Rajas, writes that: "Whatever the stories and traditions may be, the first ruler of this House was converted to Islam and as a symbol of this Hindu tradition, even now a »Bhadra deepa« or a full-lighted auspicious lamp is maintained in a southern room of this House. Near the lamp there is a bed spread over a coat. Another tradition related to this lamp was that it was kept facing the Arabian sea in memory of the ancestor of the House who went to Mecca ${ }^{16}$. The House had strictly maintained the Hindu custom of the matrilineal succession which was contradictory to the rules of Shariat (Kurup, 2002, p. 16).

The fact that marumakkathayam was observed in the coastal areas of Ponnani, Calicut and North Malabar indicates that the conversion is the root cause for its prevalence among Muslims. The Arabs had settled in these coastal towns to carry out their trading occupation. In North Malabar, besides Nairs, Mukkuvans or fishermen and Tiyas also followed matriliny (Innes, 1987, pp. 125126). As the Tiyas constitute the major chunk of the population of the inland and Mukkuvans of the coastal areas, conversion from these sections made the entire Muslims of North Malabar followers of matrilineal system. The prominent Muslim communities of Calicut and Tellichery, Koyas and Keyis respectively, became the adherents of this tradition as they were converts from the Nairs. In Calicut from around eight Nair families like Ambadi Kovilakam ${ }^{17}$, Valiya Kovilakam, Cheriya Kovilakam, Erambira Kovilakam, Padinhare Kovilakam, Kizhakke Kovilakam and Kuttichi Tampuratti more than four hundred women were allowed by Zamorin to become the wives of the Arabs (Mammed Koya, 2012, p. 68). The Ali Rajas also followed matriliny because, the founder of the dynasty, a king of the Kolathiri family, in Kolathunad, embraced Islam and his descendents followed matrilineal system (Kunjan Pillai 1970, p. 310). Thus the argument is summarized that the Mappila community that was doctrinally rooted in the patriarchal system followed matriliny as the continuation of their former practice that existed before their conversion to Islam.

Some scholars hold the view that the itinerant nature of the Arab traders in Kerala is a factor for the emergence of marumakkathayam among Mappilas. It is pointed out that for the Arab traders in Malabar it was not possible to settle down for a long time in one particular place attaching themselves to the same wife or wives. Much of their time was spent at sea and the remaining period was distributed over their stay in different ports. In the different ports of

16 There is a myth among the Muslims of Kerala that the last Chera king had partitioned his domain among his descendents and left for Mecca, the holy land in the present Saudi Arabia, to accept Islam.

17 Kovilakams were the big households of the Nairs. 
anchor they were required to stay for periods of varying duration and during such periods it was customary for them to marry the local women. When it was time for them to leave the port they would also leave their wives behind and establish fresh marital connections in the new port (Mohammed Koya, 1983, pp. 18-19). The temporary stay in their wives' houses and the itinerant nature of their profession made the women (wives) the custodians of the families. This temporary marriage known as $m u t^{\prime} a$ and the mother-right system have helped the Arab traders to accustom themselves with the marumakkathayam easily.

However this theory doesn't seem to be sufficient to explain the cause of the matriliny. The Arabs had trade contacts with various parts of Asia and Africa and they were responsible for the propagation of Islam in these regions. However, a matrilineal systems did not exist in these territories except for a few instances. The matrilineal principles run parallel to the Islamic system of inheritance. In India alone the Muslims of Malabar follow this institution. This was a strange phenomenon as Muslims elsewhere in the country were patrilineal and a great bulk of the Mappilas who lived in the interior parts of the North Malabar as well as in the South Malabar were following the Sharia laws. These factors justify the conversion theory of the emergence of the matriliny and any scholar who has worked on the social history of Kerala shares this view (Kunjan Pillai, 1970; Miller, 1976; Ibrahim Kunju, 1989; Mohammad Koya, 1983). This institution is considered as the example for social adaptation of the indigenous cultural practices by the Mappilas (Miller, 1976, p. 252). It is a paradigm of the indigenization of Islamic inheritance in the social milieu of Kerala.

At the same time, there is a possibility of the question, why the followers of a monolithic ideology has accepted matriliny? The answer is explained as: "It is very natural and probable that when a large section of a community adopts a new religion the converts should retain many of their pre conversion customs and social institutions. Hence it is possible that the converts should retain the rules of inheritance to which they were previously subject and it is also extremely likely that heads of the new religion should encourage conversion by making the change as easy and agreeable as possible to the new converts" (Mohammed Koya, 1983, p. 65).

The criticisms against this practice on the part of the Islamic scholars also substantiate the argument of Hindu influence. According to them the new system is an aberration from the true teachings of the religion. Shaikh Zainuddin, the renowned Islamic scholar of sixteenth century has denounced the believers for their adherence to matriliny. He rebukes the Muslims: "This custom of denying inheritance right to male children, following the Hindu practice, has crept into most families of the Muslim community in Kannur and the neighboring places. They read the Qur'an; they learn it by heart; they recite it beautifully; they acquire religious learning; they perform prayers and other forms of worship; yet, it is extremely strange and surprising that this custom prevails among them" (Zainuddin, 2006, p. 40).

This statement points out that the Muslims adopted the matrilineal system from the Hindu society. 


\section{CONCLUSION}

From circumstantial evidence it can be concluded that the Muslim matriliny was due to the conversion of Hindus especially the matrilineal Hindu communities into Islam. When they embraced the new religion they didn't discard some of their old habits and traditions. Matriliny was one among them. The temporary nature of the stay of the Arabs on the Malabar Coast might have strengthened the existing system of family structure in the land. The economic self-sufficiency and the security feeling of the joint family system under the matriliny have given them more freedom to pursue their maritime exercises. This institution is considered as the example for social adaptation of the indigenous cultural practices by the Mappilas. In other words, it is a paradigm of the indigenization of Islamic inheritance in the social milieu of Kerala. This is the reason for their acceptance of this unusual social custom, even though it was against the spirit of the Islamic shariah.

\section{REFERENCES}

1. Dale, S. F. (1980). The Mappilas of Malabar 1498-1922: Islamic Society on The South Asian Frontier. Oxford: Clarendon.

2. Ibrahimkunhu, A. P (1989). Mappila Muslims of Kerala: Their History and Culture. Trivandrum: Sandhya Publications.

3. Innes, C.A (1908) (1987 rpt). Malabar Gazetteer, Thiruvananthapuram: Kerala Gazetteers.

4. Kunjan Pillai, P. N. (1970). Studies in Kerala History. Trivandrum: Sathyaniketanam.

5. Kurup, K. K. N. (1975) The Ali Rajas of Cannanore. Kozhikkode: Publication Division, Calicut University

6. Kurup, K. K. N., \& Ismail, E. (2008). The Keyis of Malabar: a Cultural Study. Vatakara: Malabar Institute for Research and Development.

7. Logan, W. (2000). Malabar Manual, Vol. I, New Delhi: Asian Educational Services.

8. Mammed Koya, P. (2012). Kozhikkotte Muslimkalude Charithram [History of the Muslims of Calicut]. Kozhikkode: Focus Publications.

9. Miller, R. E. (1992). Mappila Muslims of Kerala. Madras: Orient Longman.

10. Mohammed Koya, S. M. (1983). Mappilas of Malabar. Calicut University: Sandhya Publications.

11. Sreedhara Menon, A. (2008). Cultural Heritage of Kerala. Kottayam: D. C. Books.

12. Zainuddin, S. (2006). Tuhfat al-Mujahidin, trans. by S. Muhammed Husayn Nainar. Kuala Lumpur: Other Books \& Islamic Book Trust. 